\title{
SOSIALISASI TENTANG PENERAPAN PROTOKOL KESEHATAN PENCEGAHAN COVID-19 DI KABUPATEN BATU BARA PROVINSI SUMATERA UTARA
}

\section{Felix Kasim ${ }^{1}$, Sri Melda Br Bangun' ${ }^{1}$, Anggi Isnani Parinduri ${ }^{1}$, Henri Gudmen Sihite $^{1}$, Ika Nur Saputri ${ }^{2}$, Kuat Sitepu ${ }^{3}$}

\author{
${ }^{1}$ Program Studi Kesehatan Masyarakat, Institut Kesehatan Medistra Lubuk Pakam \\ 2Program Studi Kebidanan Program Sarjana, Institut Kesehatan Medistra Lubuk Pakam \\ ${ }^{3}$ Program Studi Keperawatan Program Sarjana, Institut Kesehatan Medistra Lubuk Pakam \\ JIn. Sudirman No.38 Lubuk Pakam, Kabupaten Deli Serdang, \\ Sumatera Utara - Indonesia \\ *email korespondensi author: felixkasim@medistra.ac.id
}

DOI $10.35451 / j p k . v 1 i 1.711$

\begin{abstract}
Abstrak
Pandemi COVID-19 menjadi masalah kesehatan dunia sejak akhir tahun 2019, kasus ini meningkat dan penyebarannya sangat cepat hingga keseluruh dunia, salah satunya Indonesia. Kabupaten Batu Bara menjadi salah satu kabupaten yang mengalami peningkatan kasus terkonfirmasi COVID-19. Berbagai kebijakan sudah ditetapkan untuk menekan angka penyebaran COVID-19. WHO sudah melakukan berbagai upaya dan himbauan agar masyarakat di seluruh dunia menggunakan masker, mencuci tangan menggunakan sabun, menggunakan hand sanitizer, menghindari kerumunan, menjaga jarak (social distancing) dan tetap di rumah (stay at home). Pada penerapannya, masyarakat belum sepenuhnya memahami pentingnya melakukan protokol kesehatan yang disebabkan karena masih rendahnya pengetahuan masyarakat di tempat pelaksanaan pengabdian tentang bahaya penularan COVID-19 dan masih jarangnya sosialisasi terkait pentingnya pencegahan penularan COVID-19 oleh tenaga kesehatan setempat. Adapun tujuan dari penulisan ini adalah untuk memberikan sosialisasi tentang penerapan protokol kesehatan. Metode pelaksanaan kegiatan berupa observasi dan sosialisasi tentang protokol kesehatan pencegahan COVID-19 pada masyarakat. Berdasarkan hasil dari kegiatan yang telah dilakukan masyarakat lebih memahami protokol kesehatan dalam upaya pencegahan, diharapkan berdampak terhadap perubahan perilaku masyarakat agar lebih mematuhi dan menerapkan protokol kesehatan pencegahan COVID-19 sehingga terjadi penurunan kasus secara signifikan.
\end{abstract}

Kata kunci: COVID-19, Sosialisasi, Pencegahan

\begin{abstract}
The COVID-19 pandemic has become a world health problem since the end of 2019, this case is increasing and spreading rapidly throughout the world, including Indonesia. Batu Bara Regency is one of the districts experiencing an increase in confirmed cases of COVID-19. Various policies have been set in order to prevent and control the spread of COVID-19. WHO has made various efforts and appealed to people around the world to use masks, wash hands with soap, use hand sanitizers, avoid crowds, maintain social distance and stay at home. In its application, the community does not fully understand the importance of implementing health protocols due to the low knowledge of the community in Datuk Lima Puluh Subdistrict, Batu Bara Regency about the dangers of COVID-19 transmission and the lack of socialization related to the importance of preventing COVID-19 transmission by local
\end{abstract}


Received: 04 June 2021 :: Accepted: 30 June 2021 :: Published: 31 Desember 2021

health workers. The purpose of this paper is to provide socialization about the implementation of the COVID-19 prevention health protocol in Batu Bara Regency, North Sumatra Province. The method of implementing the activity is in the form of observation and socialization of the COVID-19 prevention health protocol to the community. Based on the results of the activities that have been carried out, the community has a better understanding of health protocols in prevention efforts, it is hoped that it will have an impact on changing people's behavior to better comply with and implement the COVID-19 prevention health protocol so that there will be a significant decrease in cases.

Keywords: COVID-19, Socialization, Prevention

\section{Pendahuluan}

Pada awal Maret 2020 Indonesia telah melaporkan 2 (dua) kasus konfirmasi COVID-19, kasus meningkat dan menyebar dengan cepat ke seluruh wilayah Indonesia (Kemenkes RI, 2020). Provinsi Sumatera Utara mengalami peningkatan kasus terkonfirmasi COVID-19, tercatat bahwa sebanyak 10.965 total kasus terkonfirmasi COVID-19 (Media Center COVID-19 Provinsi Sumatera Utara, 2020).

Hampir seluruh wilayah di Sumatera Utara, baik kabupaten/kota menunjukkan peningkatan kasus setiap harinya. Kabupaten Batu Bara menjadi salah satu kabupaten yang mengalami peningkatan kasus terkonfirmasi COVID-19. Keputusan Bupati Batu Bara Nomor 196/ BPBD/ 2020 tentang Penetapan Status Siaga Darurat Bencana Corona Virus Disease 2019 (COVID-19) di Kabupaten Batu Bara. Hal ini mengindikasikan bahwa ancaman virus COVID-19 sangat membahayakan masyarakat di Kabupaten Batubara. Oleh karena itu, Kabupaten Batubara telah menetapkan gugus tugas dalam menghadapi pandemi COVID-19 tersebut.

Berdasarkan laporan Gugus Tugas Percepatan Penanganan COVID19 di Kabupaten Batu Bara diperoleh data bahwa kasus konfirmasi sebanyak 119 orang. Hal ini berarti telah terjadi peningkatan kasus terkonfirmasi COVID-19 di Kabupaten Batubara.
Strategi pencegahan yang dilakukan oleh Pemerintah dalam menekan angka kejadian COVID-19 salah satunya adalah dengan penerapan protokol kesehatan melalui Keputusan Menteri Kesehatan Republik Indonesia No. 382/2020 Tentang Protokol Kesehatan Bagi Masyarakat di Tempat dan Fasilitas Umum dalam Rangka Pencegahan dan Pengendalian COVID-19 (Kemenkes RI, 2020).

Survei pendahuluan yang dilakukan peneliti terhadap 30 orang penduduk di Kecamatan Datuk Lima Puluh Kabupaten Batu Bara menunjukkan bahwa 9 orang di antaranya sudah melakukan protokol kesehatan pencegahan COVID-19 dengan menggunakan masker, mencuci tangan pakai sabun, dan menjaga jarak, sedangkan 21 orang lainnya belum melakukan protokol kesehatan. Hasil survei awal juga menunjukkan masih rendahnya masyarakat yang melakukan protokol kesehatan.

Penelitian Alamsyah dan Marlina (2016) membuktikan bahwa faktor umur berhubungan dengan kepatuhan protokol kesehatan COVID-19. Ketidakpatuhan melakukan protokol kesehatan COVID-19 banyak dilakukan pada usia 17-45 tahun. Hal ini didukung oleh Survei Balitbangkes Kemenkes RI pada Tahun 2020 yang menjelaskan bahwa $83,58 \%$ ketidakpatuhan terjadi pada rentang usia 17-45 tahun. Faktor dukungan keluarga juga menentukan 
Received: 04 June 2021 :: Accepted: 30 June 2021 :: Published: 31 Desember 2021

keberhasilan dalam menerapkan protokol kesehatan pencegahan COVID19, kurangnya dukungan keluarga disebabkan anggota keluarga yang lain juga tidak mengetahui secara mendalam tentang bahaya penyakit COVID-19 sehingga mereka kurang peduli untuk memotivasi keluarganya dalam melakukan protokol kesehatan yang dianjurkan pemerintah Kabupaten Batu Bara.

\section{Metode}

Metode yang digunakan berupa observasi dan sosialisasi penyuluhan kesehatan terkait dengan penerapan protokol COVID-19 kepada masyarakat dengan tujuan peningkatan kepatuhan dalam upaya pencegahan COVID-19. Kegiatan PKM ini dilakukan di Kecamatan Datuk Lima Puluh Kabupaten Batu Bara. Sasaran pada kegiatan PKM ini adalah masyarakat yang berada di Kecamatan tersebut yang berjumlah 23.717 orang.

\section{Hasil dan Pembahasan}

\subsection{Kepatuhan} Berdasarkan Responden

Karakteristik responden berupa umur, jenis kelamin dan pendidikan berdasarkan kepatuhan responden dapat disajikan dalam diagram batang berikut

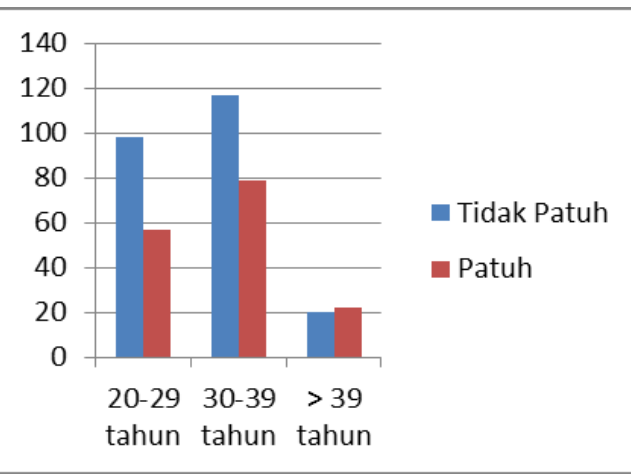

Gambar 1. Kepatuhan Responden Berdasarkan Umur

Gambar 1. Menunjukkan bahwa responden yang tidak patuh berumur 20-29 tahun sebanyak 98 orang (24,9\%), 30-39 tahun sebanyak 117 orang $(29,8 \%)$ dan $>39$ tahun sebanyak 20 orang $(5,1 \%)$.

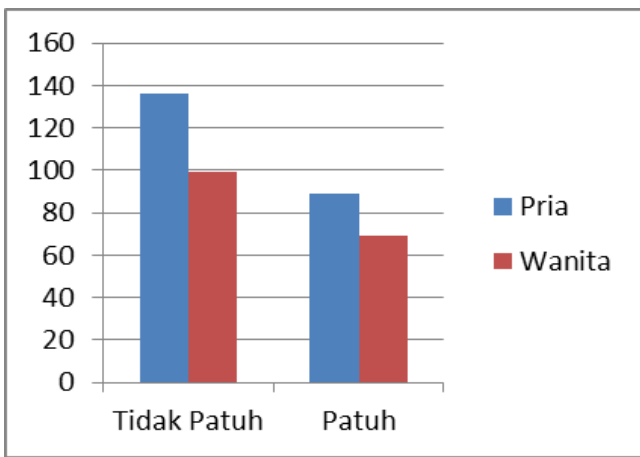

Gambar 2. Kepatuhan Responden

Berdasarkan Jenis Kelamin

Gambar 2. Menunjukkan bahwa responden yang tidak patuh jenis kelamin pria berjumlah 136 orang $(34,6 \%)$ dan wanita berjumlah 99 orang $(25,2 \%)$.

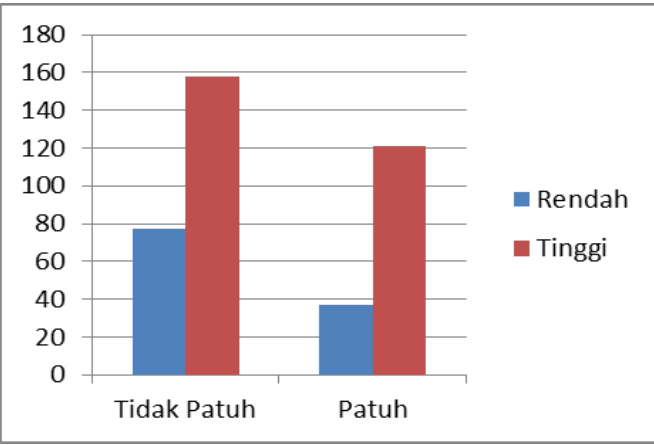

Gambar 3. Kepatuhan Responden Berdasarkan Pendidikan

Gambar 3. Menunjukkan bahwa responden yang tidak patuh pendidikan rendah berjumlah 77 orang $(19,6 \%)$ dan tinggi berjumlah 158 orang $(40,2 \%)$.

\subsection{Sosialisasi tentang Protokol Kesehatan Pencegahan COVID- 19 di Kabupaten Serdang Bedagai}

Berdasarkan hasil yang telah dilakukan, dapat dilihat bahwa terdapat 235 orang masyarakat yang tidak mematuhi protokol kesehatan pencegahan COVID-19. Sosialisasi yang diberikan kepada masyarakat pada kegiatan PKM ini meliputi pentingnya penggunaan masker yang sesuai dengan standar saat beraktivitas di luar rumah, pentingnya menjaga jarak (minimal 1 meter) saat beraktivitas dan 
Received: 04 June 2021 :: Accepted: 30 June 2021 :: Published: 31 Desember 2021

menjaga kebersihan diri dengan cara mencuci tangan dengan sabun di air yang mengalir. Penggunaan masker yang berlapis untuk menutupi hidung dan mulut hingga dagu, jika harus keluar rumah atau berinteraksi dengan orang lain. Jika menggunakan masker, sebaiknya gunakan masker medis yang dilapisi lagi dengan masker kain. Mencuci tangan di bawah air yang mengalir dengan sabun saat menyentuh sesuatu atau dengan menggunakan cairan antiseptik (hand sanitizer). Menjaga jarak minimal 1 meter dengan orang lain serta menghindari kerumunan dan keramaian pada saat berpergian keluar rumah. Jika tidak memungkinkan melakukan hal tersebut, maka dapat dilakukan rekayasa administrasi dan teknis lainnya. Rekayasa administrasi dapat berupa pembatasan jumlah orang, pengaturan jadwal, dan sebagainya. Sedangkan rekayasa teknis antara lain dapat berupa pembuatan partisi, pengaturan jalur masuk dan keluar, dan Iain sebagainya.

Pemberian sosialisasi ini dilakukan langsung secara tatap muka kepada masyarakat dengan menggunakan media leaflet. Masyarakat dengan antusias mendengarkan penjelasan yang diberikan tim PKM.

\section{Kesimpulan}

Masyarakat di Kecamatan Datuk Lima Kabupaten Batu Bara berjumlah 393 orang dan terdapat 235 orang yang tidak patuh terhadap protokol kesehatan pencegahan COVID-19. Setelah dilakukan sosialisasi, pengetahuan masyarakat tentang COVID-19 dapat meningkat sehingga masyarakat mematuhi protokol kesehatan. Edukasi tentang penerapan protokol kesehatan terus dilakukan untuk menumbuhkan kesadaran diri kepada masyarakat.

\section{Ucapan Terima Kasih}

Terima kasih diucapkan kepada Institut Kesehatan Medistra Lubuk Pakam, Lembaga Penelitian dan Pengabdian kepada Masyarakat, Kepala Camat Datuk Lima Puluh, dan semua pihak yang telah mendukung kegiatan
PKM ini yang tidak dapat disebutkan satu per satu.

\section{Daftar Pustaka}

Alamsyah, Agus dan Tuti Marlina. 2016. Faktor-Faktor yang Berhubungan dengan Cakupan Menelan Obat Massal Pencegah Filariasis. Journal Endurance, 1(1), 17-22.

Kemenkes RI.info InfeksiiEmerging Kementerian Kesehatan RI [Internet].i2020 [updated 2020 March 30; cited 2020 March 31]. Available from: https:// infeksiemerging.kemkes.go.id/.

Notoatmodjo, S. 2010. Metodologi Penelitian Kesehatan. Jakarta: Rineka Cipta.

Purnamasari, I dan Raharyani, A E . 2020. Tingkat Pengetahuan dan Perilaku Masyarakat Kabupaten Wonosobo tentang COVID-19. Jurnal Ilmiah Kesehatan, https://ojs.unsiq.ac.id/index.php /jik/ article/view/1311/783.

Syadidurrahmah,iFidah, iFikaiMuntahay, SitiiZakiyatul Islamiyah, Tri Aulia Fitriani, Hoirun Nisa. 2020. Perilaku Physical Distancing Mahasiswa UIN Syarif HidayatullahiJakarta pada Masa Pandemi COVID-19. Perilaku daniPromosiiKesehatan:

Indonesian Journal of Health Promotion and Behavior. 2020; 2(1): 29-37.

WHO. 2020. Strategis Preparedness and Response Plan for the South East Asia Region.

Zhong BL dkk. 2020. Knowledge, Attitudes and Practices Towards COVID-19 Among Chinese Residents during the Rapid Rise Period of the COVID 19 outbreak. International Journal of Bilogical Science, Diakses di https://www.ncbi.nlm.nih.gov 